This is the pre-peer reviewed version of the following article: Singh, S. P.,

Burgess, G. and Singh, J. (2008), Performance comparison of thermal insulated

packaging boxes, bags and refrigerants for single-parcel shipments. Packaging

Technology and Science, 21: 25-35. doi: 10.1002/pts.773, which has been

published in final form at http://onlinelibrary.wiley.com/doi/10.1002/pts.773/abstract

\title{
Performance Comparison of Thermal Insulated Packaging Boxes, Bags and Refrigerants for Single-parcel Shipments
}

\author{
S. P. Singh \\ School of Packaging, Michigan State University, East Lansing, Michigan, USA \\ Gary Burgess \\ School of Packaging, Michigan State University, East Lansing, Michigan, USA \\ Jay Singh \\ College of Business, Cal Poly State University, San Luis Obispo, California, USA
}

\section{ABSTRACT}

A range of packaging solutions exists for products that must be kept within a specific temperature range throughout the supply-and-distribution chain. This report summarizes the results of studies conducted over a span of 2 years by the Consortium for Distribution Packaging at Michigan State University. Thermal insulation packaging materials such as expanded polystyrene, polyurethane, corrugated fibreboard, ThermalCor ${ }^{\circledR}$ and other composite packaging such as thermal insulating bags were studied. Phase change materials such as gel packs were also evaluated. Properties such as R-value, melting point and heat absorption were examined and are reported.

KEY WORDS: temperature; insulation; packaging; gel packs; parcel; shipping; phase change materials

\section{INTRODUCTION}

Thermal abuse is a primary concern during the distribution of temperature-sensitive goods such as pharmaceutical, food, electronic and horticulture products. Insulated packaging can maintain product 
temperatures within acceptable ranges and slow down the deterioration of the product in the distribution environment until it reaches the consumer. In addition to high resistance to the transfer of heat, a good insulating material must have various characteristics, depending upon the application. For packaging applications, low cost, low moisture susceptibility, ease of fabrication and transportation, consumer appeal, and mechanical strength are the most relevant characteristics.

Distribution and marketing of temperature-sensitive goods can be achieved by three different modes, namely carrier-controlled thermal chain, one-way systems and two-way systems. Carrier controlled thermal chains provide refrigerated trailers for the transportation of goods over longer distances. They attempt to keep products within the required temperature range and allow the use of ground freight instead of air. The disadvantages of this method include the higher cost of shipping smaller lots and the restricted number of destinations and temperature ranges available. One-way systems offer advantages of rapid package design and validation using various insulated shipping containers and phase change materials (PCMs). Two-way systems are the third category of solutions available for the distribution of temperature-sensitive products. Reusable shipping containers, which fall in this category, typically have an impact-resistant exterior and offer improved temperature control. But it is difficult to monitor the costs and it requires high inventories.

The choice of distribution system is governed by payloads, transit time, temperature sensitivity of the product, customer acceptance and cost. One-way systems have emerged as the most popular because of their ease of application. Insulated containers provide insulation using different material combination choices and refrigerants in order to maintain the desired temperatures and preserve product quality.

\section{I.I Heat transfer}

Heat flows by means of three mechanisms: conduction, convection and radiation. ${ }^{1}$ Conduction is the molecule-to-molecule transfer of kinetic energy. One molecule becomes energized and, in turn, 
energizes adjacent molecules. A cast-iron skillet handle heats up because of conduction through the metal. Convection is the transfer of heat by physically moving heat from one place to another. Forcedair heating systems work by moving hot air from one place to another. Radiation is the transfer of heat through space by electromagnetic waves (radiant energy). A campfire emits enough radiant heat to warm objects at a distance.

In packaging applications, one or more of the above-mentioned modes of transmission usually plays a role. The wall thickness of shipping containers (conduction), the number of surfaces (convection) and the number of reflective surfaces such as aluminum foil (radiation) determines the insulating ability of a container. ${ }^{2}$ Any material that offers a high resistance to the transfer of heat by conduction, convection or radiation serves as a form of insulation. Most insulating materials utilize low thermal conductivity as a means of restricting the transfer of heat, although radiation and convection are also significant. Radiation can be restricted using a material with high reflectivity such as aluminum foil.

The most common insulating material used for packaging applications is plastic foam, which consists of small air spaces surrounded by solid walls. The low thermal conductivity of foam is attributed to the low thermal conductivity of the air enclosed within the cells and the relatively small amount of solid material through which heat may be conducted. Some cellular plastics depend on the low thermal conductivity of gases such as chlorofluorocarbons, hydrofluorocarbons or hydrochlorofluorocarbons (blowing agents) inside their cells to maintain lower thermal conductivity. ${ }^{3}$ Although heat transfer in cellular plastics occurs by all three mechanisms, conduction of heat through trapped gases in foam is the primary mechanism of heat transfer in comparison with convection or radiation, since gases occupy $90-98 \%$ by volume. $^{3}$

Other factors that affect thermal conductivity of cellular plastics are temperature and moisture. Thermal conductivity of most materials decreases with temperature. Absorbed moisture, depending on the 
temperature on either side of the insulation, is known to reduce the thermal resistance of cellular plastics because it replaces the gas in the cellular structure. It can also result in latent heat transfer through evaporation and condensation. ${ }^{3}$

The four principal materials employed by the packaging industry today include fibres, foams, reflectors and loose-fills. Most fibrous insulation has very low density and relies on trapped air to slow the heat transfer. The fibres are held together by means of organic binders that give it structural strength. Foams are either open- or closed-cell structures. Closed-cell foam entraps gases to reduce the conduction portion of heat transfer. Open-cell foam uses similar air pockets, and retards heat transfer by means of creating a tortuous path. Conduction in foams is less than that for fibrous insulation due to the nature of the cell structure. Reflective surfaces have low emittance and block a large portion of radiant heat flow. When used in vacuum systems, foil reflectors are often layered between thin fibrous materials. Systems designed for use with air are less energy efficient, and can cost much more than other insulative means. Loose-fill insulation generally consists of a mass of unstructured fibres composed of rock slag, glass or alumina-silica, which are packed into cavities. Powders, such as perlite, silica aerogel and adiatomaceous earth, can also be used. ${ }^{4}$

\section{I.2 PCMs}

Changing the physical state of the material from solid to liquid requires the addition of heat. When energy is supplied to a solid at its melting point, the energy causes the solid to melt without changing its temperature. During a phase change, the energy supplied goes into breaking the molecular bonds that make it a solid. Latent heat is the term used to describe the heat energy that accompanies a change of state without a corresponding change in temperature.

PCMs take advantage of latent heat. PCMs can be designed to melt within a narrow temperature range. This temperature range is determined by the hydrocarbon molecule length of the PCM. ${ }^{5}$ When a PCM is 
exposed to heat, its phase change particles absorb the heat and melt. When it is cooled, the phase change particles return to a solid state. PCMs can move through these cycles indefinitely, making them ideal candidates for reusable containers.

\section{I.3 Thermal conductivity}

The ease with which heat flows through a material is measured by its thermal conductivity. The higher the conductivity, the easier the heat flow. Table 1 shows the conductivities of various materials used in packaging. A vacuum does not conduct heat. Polyurethane foam is a better insulator than expanded polystyrene (EPS), and glass conducts heat easily.

\begin{tabular}{|lc|}
\hline \multicolumn{2}{|c|}{ Table I.Thermal conductivities } \\
Material & \\
& \\
\hline Glass & Thermal conductivity $\left(\mathrm{W} / \mathrm{m}^{\circ} \mathrm{C}\right)$ \\
Polyethylene (PE) foam & 0.780 \\
Wood (dry) & 0.076 \\
Polyurethane (PU) foam & 0.120 \\
EPS & 0.030 \\
Air & 0.046 \\
Vacuum & 0.026 \\
Cardboard/corrugated & 0 \\
& 0.078 \\
\hline
\end{tabular}

\section{I.4 Cold chain distribution requirements}

Heat is the primary environmental hazard in the transportation of temperature-sensitive products. The quality of perishables can be significantly reduced after only a few hours of exposure to unfavourable temperatures. Delicate pharmaceutical products such as vaccines need to be kept within a restricted temperature range during shipping. Biological products such as blood samples can be rendered completely ineffective or toxic if not kept cool. Platelets require $20-24^{\circ} \mathrm{C}$, and frozen red blood cells require $-65^{\circ} \mathrm{C} .{ }^{7}$ Frozen food and fresh fruits and vegetables must be kept cold for best retention of food value and appearance. Higher temperature provides an environment for bacterial growth in certain 
foods, resulting in shortened shelf life of processed foods such as seafood, meat, poultry and dairy products. Fish requires a storage temperature of near $0^{\circ} \mathrm{C}$ until it is ready to be consumed. For every $10^{\circ} \mathrm{C}$ increase in the temperature of fish, the shelf life is halved. ${ }^{8}$ Cooling is the most effective method of slowing the ripening process that leads to deterioration, but not all products have the same requirements. Many tropical products suffer from 'freezer burn' if the temperature is too low but for other products the same temperature may not be low enough to effectively retard deterioration. ${ }^{9}$ Horticulture products such as cut flowers require temperatures between 0 and $12^{\circ} \mathrm{C}$.

\section{I.5 Study objectives}

The objectives of this study were:

- to measure and compare the R-values of various package systems; and

- to measure and compare the melting points and heat absorption rates of various PCMs commonly used in parcel shipment.

\section{INSULATED PACKAGING SYSTEMS TESTED}

\subsection{Insulated packaging}

There are a number of options available for selecting an insulated container for one-way distribution. Only economical solutions were selected for this study. Table 2 lists the various types of insulated containers and bags tested. The same are shown in Figures 1 through 12.

\subsection{PCMs}

Temperature control for products during shipping can be improved with the use of PCMs. They are made of non-toxic, food-grade, FDA-approved ingredients sealed in durable, leak-proof packaging 
Table 2. Insulated containers and bags tested

\begin{tabular}{|c|c|c|c|}
\hline Package & Description & Inside dimensions (cm) & Comments \\
\hline la & $\begin{array}{l}\text { C-Flute corrugated } \\
\text { fibreboard* box with 19- } \\
\text { mm-thick EPS foam panels }\end{array}$ & $27.9 \times 27.9 \times 29.5$ & $\begin{array}{l}\text { Foam panels line the top, bottom and } \\
\text { four sides of a full overlap corrugated } \\
\text { box }\end{array}$ \\
\hline Ib & $\begin{array}{l}\text { C-Flute corrugated } \\
\text { fibreboard* box with I3- } \\
\text { mm-thick EPS foam panels }\end{array}$ & $27.9 \times 27.9 \times 29.5$ & $\begin{array}{l}\text { Foam panels line the top, bottom and } \\
\text { four sides of a full overlap corrugated } \\
\text { box }\end{array}$ \\
\hline 2 & $\begin{array}{l}\text { C-Flute corrugated } \\
\text { fibreboard box, } 4 \mathrm{~mm} \text { thick }\end{array}$ & $27.9 \times 27.9 \times 29.5$ & Full overlap corrugated box \\
\hline 3 & Oyster ThermalCor $\AA^{\dagger}$ box & $27.9 \times 27.9 \times 29.5$ & $\begin{array}{l}\text { Foam sandwiched between } \\
\text { paperboard faces }\end{array}$ \\
\hline 4 & $\begin{array}{l}\text { ThermalCor }{ }^{\circledR} \text { box with } \\
\text { ThermalCor }{ }^{\circledR} \text { tube }\end{array}$ & $27.9 \times 27.9 \times 29.5$ & $\begin{array}{l}\text { Foam sandwiched in paperboard with } \\
\text { unglued ThermalCor }{ }^{\circledR} \text { tube }\end{array}$ \\
\hline 5 & Foil ThermalCor ${ }^{\circledR}$ box & $27.9 \times 27.9 \times 29.5$ & $\begin{array}{l}\text { Foam sandwiched in foil-laminated } \\
\text { paperboard }\end{array}$ \\
\hline 6 & $\begin{array}{l}\text { Foil ThermalCor }{ }^{\circledR} \text { box with } \\
4.8 \mathrm{~mm} \text { foil jacket insert }\end{array}$ & $27.9 \times 27.9 \times 29.5$ & $\begin{array}{l}\text { Foam sandwiched in foil-laminated } \\
\text { paperboard and a } 4.8 \mathrm{~mm} \text { flexible foil } \\
\text { bag }\end{array}$ \\
\hline 7 & EPS container with lid & $27.9 \times 27.9 \times 30.5$ & $38 \mathrm{~mm}$ thick \\
\hline 8 & $\begin{array}{l}\text { Polyurethane foam moulded } \\
\text { container }\end{array}$ & $31.1 \times 26.7 \times 33.0$ & $\begin{array}{l}\text { 32-mm-thick walls with } 50 \mathrm{~mm} \\
\text { flexible foam for top and bottom }\end{array}$ \\
\hline 9 & $\begin{array}{l}\text { ThermalCor }{ }^{\circledR} \text { box in a } \\
\text { ThermalCor }{ }^{\circledR} \text { box }\end{array}$ & $\begin{array}{l}27.9 \times 27.9 \times 29.5 \\
22.9 \times 22.9 \times 24.5\end{array}$ & $\begin{array}{l}\text { Both inside and outside boxes are } \\
\text { ThermalCor } \AA \text {, with a } 13 \mathrm{~mm} \text { gap in } \\
\text { between the boxes }\end{array}$ \\
\hline 10 & $\begin{array}{l}\text { Foil-laminated ThermalCor }{ }^{\circledR} \\
\text { box in a ThermalCor }{ }^{\circledR} \text { box }\end{array}$ & $\begin{array}{l}27.9 \times 27.9 \times 29.5 \\
22.9 \times 22.9 \times 24.5\end{array}$ & $13 \mathrm{~mm}$ gap in between the boxes \\
\hline 11 & $\begin{array}{l}\text { ThermalCor }{ }^{\circledR} \text { box in a foil- } \\
\text { laminated ThermalCor }{ }^{\circledR} \text { box }\end{array}$ & $\begin{array}{l}27.9 \times 27.9 \times 29.5 \\
22.9 \times 22.9 \times 24.5\end{array}$ & $13 \mathrm{~mm}$ gap in between the boxes \\
\hline 12 & $\begin{array}{l}\text { Foil-laminated ThermalCor }{ }^{\circledR} \\
\text { box in a foil-laminated } \\
\text { ThermalCor }{ }^{\circledR} \text { box }\end{array}$ & $\begin{array}{l}27.9 \times 27.9 \times 29.5 \\
22.9 \times 22.9 \times 24.5\end{array}$ & $13 \mathrm{~mm}$ gap in between the boxes \\
\hline 13 & Keep Cool $\otimes^{\ddagger}$ insulating bag & $50.8 \times 50.8$ & $\begin{array}{l}\text { Metallized printed film, } 0.095 \mathrm{~mm} \text { PE } \\
\text { film thick, snap-in type closure }\end{array}$ \\
\hline 14 & Therm-A-Snap $\otimes^{\ddagger}$ insulating bag & $53.3 \times 52.1$ & $\begin{array}{l}\text { PE printed film, metallized film } \\
0.180 \mathrm{~mm} \text { thick, snap-in type closure }\end{array}$ \\
\hline
\end{tabular}

(Figures 13 and 14). There is a broad selection of materials available to maintain the temperature within narrow ranges between -50 and $30^{\circ} \mathrm{C}$. These materials can replace dry ice in most applications. Dry ice is used for frozen products and is cheaper than PCMs. But carriers impose a significant surcharge for carrying dry ice in air shipments since it is a regulated hazardous substance (emits carbon dioxide gas).

The PCMs used in this study are listed in Table 3. 


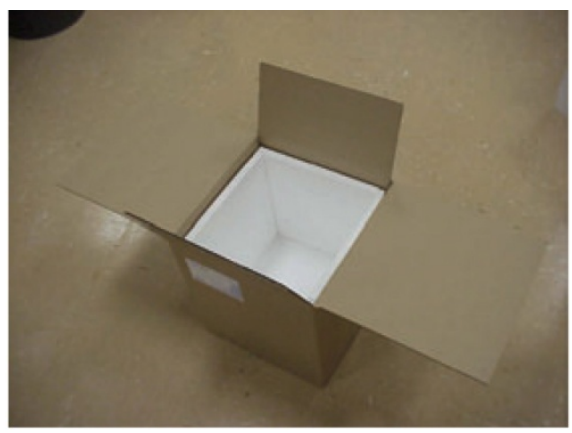

Figure 1. Corrugated box with EPS foam panels.

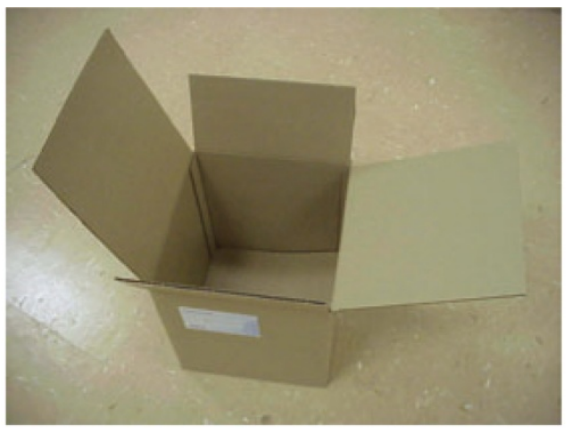

Figure 2. Corrugated fibreboard box.

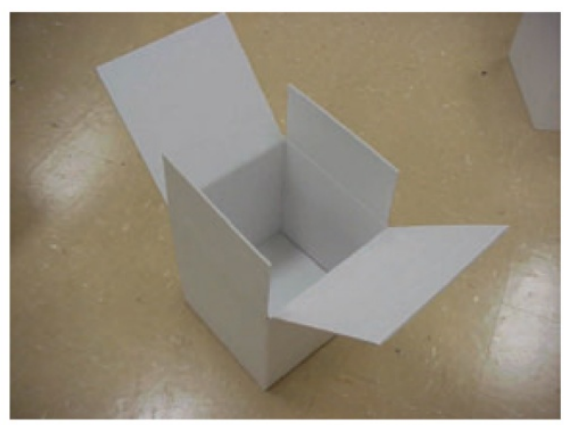

Figure 3. Oyster ThermalCor ${ }^{\circledR}$ box.

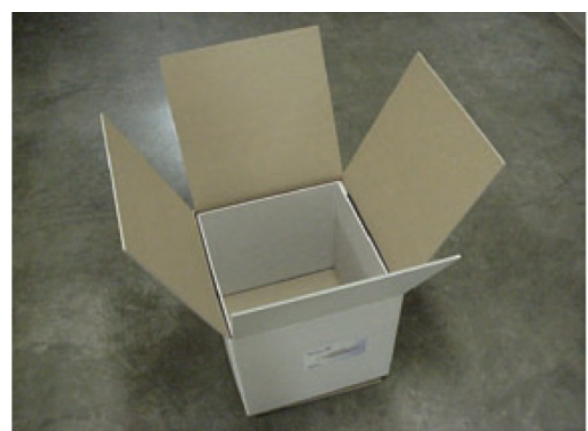

Figure 4.ThermalCor ${ }^{\circledR}$ box with ThermalCor ${ }^{\circledR}$ tube.

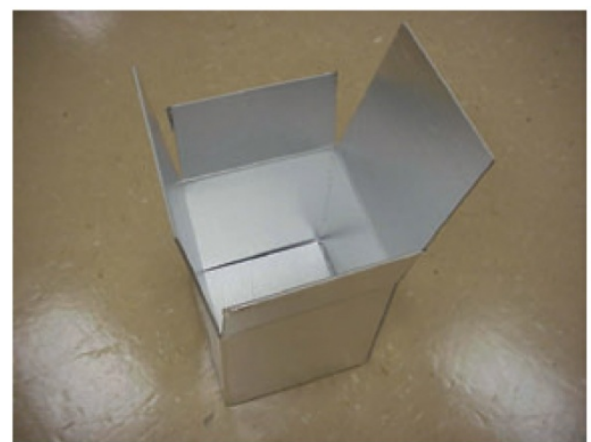

Figure 5. Foil-laminated ThermalCor ${ }^{\circledR}$ box.

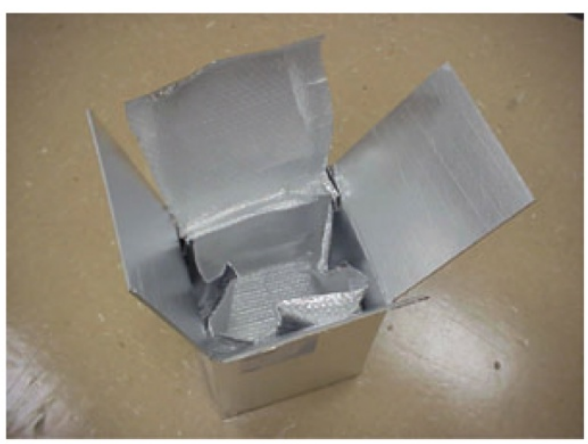

Figure 6. Foil-laminated ThermalCor ${ }^{\circledR}$ box with bag. 


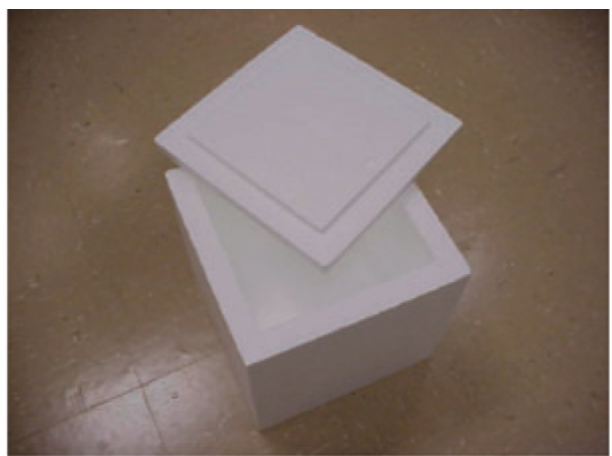

Figure 7. Expanded polystyrene (EPS cooler).

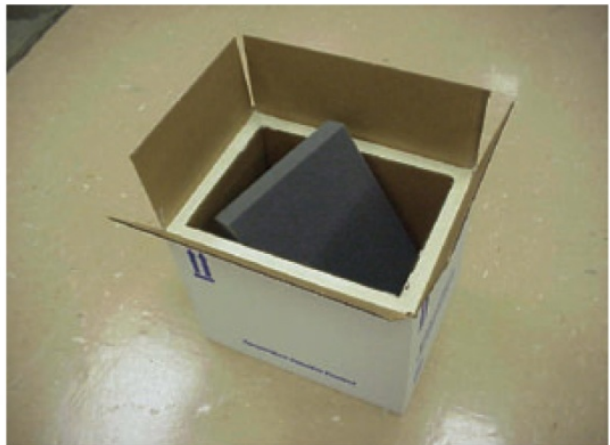

Figure 8. Moulded container box with polyurethane foam.

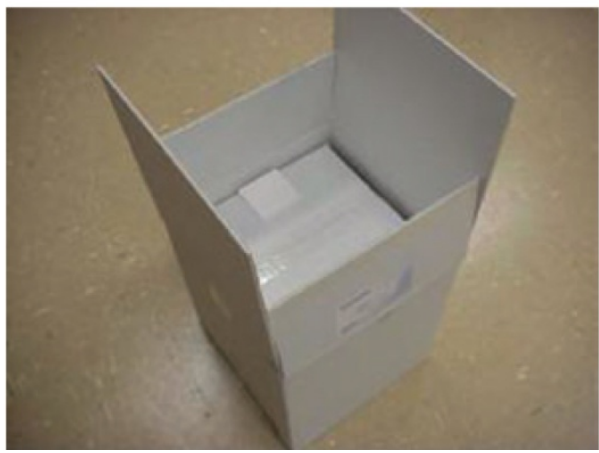

Figure 9. ThermalCor ${ }^{\circledR}$ box in a ThermalCor $^{\circledR}$ box

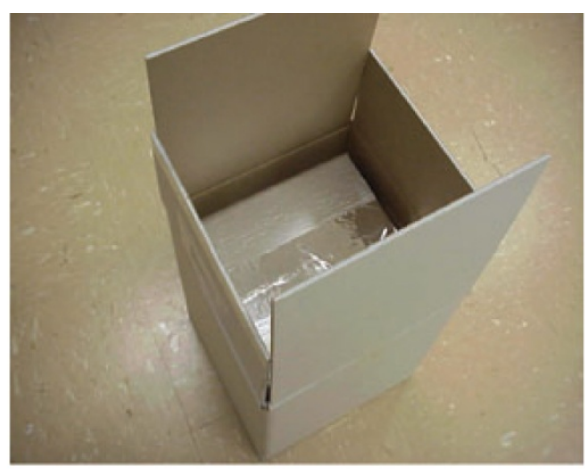

Figure 10. Foil-laminated ThermalCor ${ }^{\circledR}$ box in a ThermalCor ${ }^{\circledR}$ box.

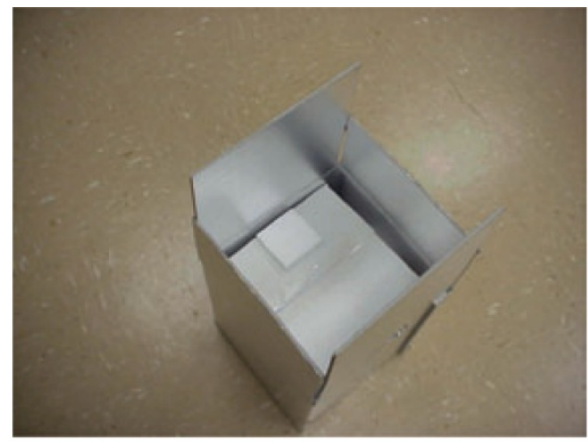

Figure 11.ThermalCor ${ }^{\circledR}$ box in a foil laminated ThermalCor ${ }^{\circledR}$ box

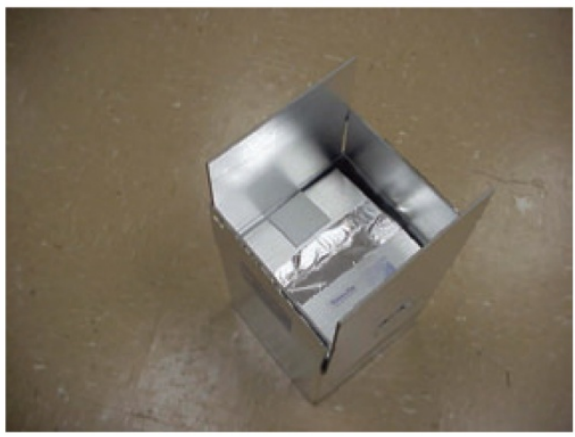

Figure 12.Foil-laminated ThermalCor ${ }^{\circledR}$ box in a foil-laminated ThermalCor ${ }^{\circledast}$ box. 


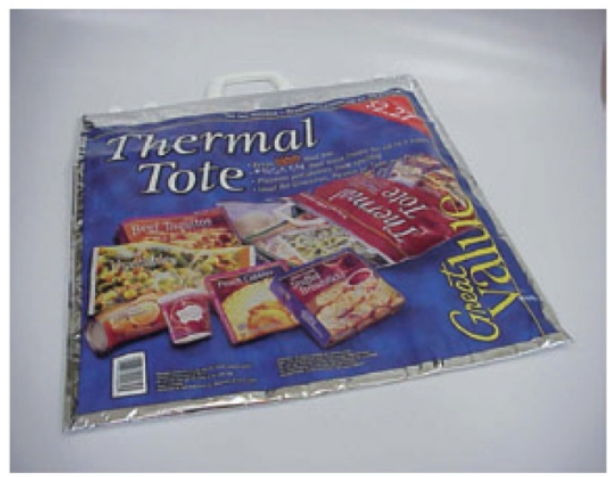

Figure 13.Keep $\mathrm{Cool}^{\circledR}$ thermal insulating bag.

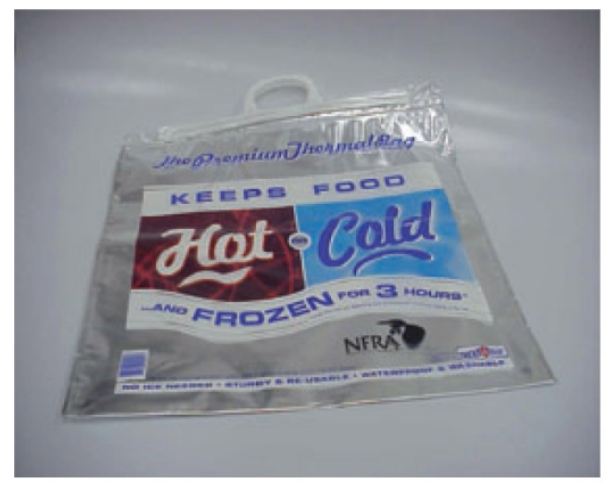

Figure 14. Therm-A-Snap ${ }^{\circledR}$ thermal insulating bag.

\section{INSTRUMENTATION ANDTEST PROCEDURES}

\subsection{Temperature monitors}

Temp Tale Model 3 temperature monitors from Sensitech Inc. (Beverly, MA, USA) were used to monitor the temperature inside the insulating containers and bags tested. The temperature monitors had stainless steel probes that could be inserted into the package to record the temperature. The devices were factory calibrated, with the accuracy tested to National Institute of Standards and Technology (NIST) traceable standards. The Sensitech Temp Tale 3 temperature monitors had a resolution of $0.1^{\circ} \mathrm{C}$ and measured in the -30 to $85^{\circ} \mathrm{C}$ range. The sensor accuracies are provided below:

sensor accuracy: 
$\pm 2^{\circ} \mathrm{C}$, from -30 to $-17.78^{\circ} \mathrm{C}$

$\pm 1^{\circ} \mathrm{C}$, from -17.78 to $+50^{\circ} \mathrm{C}$

$\pm 2^{\circ} \mathrm{C}$, from +50 to $+85^{\circ} \mathrm{C}$

\subsection{R-value measurement}

The resistance to the flow of heat through an insulating package designated as the system R-value is calculated using ice-melt tests. ${ }^{3}$ The test is based on the principal that $1 \mathrm{~kg}$ of regular ice must absorb $335 \mathrm{~kJ}$ of heat to melt. By placing a known quantity of ice inside the container, the rate of heat transfer into the container can be calculated from the quantity of ice melted at the end of test.

To conduct the ice-melt test, the ice was first preconditioned for the actual test. A sufficient quantity of regular ice (approximately $2.5 \mathrm{~kg}$ ) was placed in a non-metallic bucket and allowed to melt. After an interval of time (approximately $2 \mathrm{~h}$ ) the water from the bucket was drained. This ensured that the ice was at its melting temperature of $0^{\circ} \mathrm{C}$ uniformly and not at the freezer temperature where it was stored.

\begin{tabular}{|c|c|c|c|c|c|}
\hline \multirow[b]{2}{*}{ Product name } & \multicolumn{4}{|c|}{ Table 3. Properties of gel packs (GP) and PCMs } & \multirow[b]{2}{*}{$\begin{array}{l}\text { Latent heat } \\
(\mathrm{kJ} / \mathrm{kg})\end{array}$} \\
\hline & Type & Weight $(\mathrm{g})$ & $\begin{array}{c}\text { Size } \\
\mathrm{L} \times \mathrm{W} \times \mathrm{D}(\mathrm{cm})\end{array}$ & $\begin{array}{l}\text { Melting point } \\
\left({ }^{\circ} \mathrm{C}\right)\end{array}$ & \\
\hline Polar Pack & GP & 680 & $22.2 \times 14.6 \times 3.8$ & -1.1 & 314 \\
\hline Utek \#597 & PCM & 454 & $16.5 \times 16.5 \times 2.2$ & -4.5 & 395 \\
\hline Ice Brix & GP & 680 & $20.3 \times 15.2 \times 3.2$ & 0.6 & 349 \\
\hline Johnny Plastic XC48Y & PCM & 1190 & $27.3 \times 15.2 \times 4.4$ & -5.6 & 418 \\
\hline Kool-It Bricks & GP & 680 & $12.7 \times 12.7 \times 4.4$ & 0 & 356 \\
\hline Cold-Ice & GP & 454 & $17.8 \times 15.2 \times 2.5$ & 1.7 & 349 \\
\hline P-S Hot-Cold & GP & 680 & $21.6 \times 21.6 \times 2.5$ & -2.2 & 344 \\
\hline Guardian PCM4C & PCM & 454 & $22.9 \times 7.6 \times 2.5$ & 3.3 & 353 \\
\hline Re-Freez-R-Brix & GP & 908 & $22.9 \times 10.2 \times 3.8$ & -0.6 & 339 \\
\hline Vaxi-Safe PCM & PCM & 454 & $22.9 \times 8.3 \times 2.5$ & 3.9 & 314 \\
\hline Cryopak & GP & 680 & $41.9 \times 30.5 \times 1.9$ & 0 & 337 \\
\hline Teap TH7-PCM & PCM & 340 & $15.2 \times 10.2 \times 3.8$ & 7.2 & 383 \\
\hline
\end{tabular}

The bucket was then placed at the centre of the container, which was then closed tightly with tape, or in insulating bags, which were closed per the manufacturer's instructions. Corrugated boxes, plain 
ThermalCor ${ }^{\circledast}$ (Creative Industries, Bridgeview, IL, USA) and polyurethane containers were sealed with regular plastic tape, whereas foillaminated ThermalCor ${ }^{\circledast}$ containers were sealed with a special foil tape. The containers and bags were stored on a shelf at ambient temperature for $12 \mathrm{~h}$. The shelf was solid and five of the six sides of the container were exposed to still air. The average temperature was $23^{\circ} \mathrm{C}$ with a maximum deviation of $\pm 2^{\circ} \mathrm{C}$. At the end of the test, containers were opened and water was collected from the buckets. The weight of water collected was recorded to calculate the melt rate.

The above procedure was repeated for a test interval of $24 \mathrm{~h}$. For insulating bags the duration was $2 \mathrm{~h}$. The aim of the experiment was to have some ice left in the bucket. A few cases were noted where the entire quantity of ice was melted during the test. In such cases, the melt rate could not be calculated and the test was repeated with more ice. Melt rate is the weight of water collected in kilograms divided by the test time in hours. A constant temperature difference was maintained for as long as there is some amount of ice left inside the bucket because the ice maintains a constant temperature of $0^{\circ} \mathrm{C}$ as it melts.

The system R-value for the package was calculated using the following equation ${ }^{3}$ :

$$
\text { System } R \text {-value }=\frac{\left(\begin{array}{c}
(\text { Surface area }) \\
(\text { Temperature difference })
\end{array}\right.}{(\text { rate })(\text { Latent heat })}
$$

where:

surface area $=$ inside surface area of the package $\left(\mathrm{m}^{2}\right)$

temperature difference $\left({ }^{\circ} \mathrm{C}\right)=$ ambient temperature- melting point of ice $\left(22^{\circ} \mathrm{C}-0^{\circ} \mathrm{C}=22^{\circ} \mathrm{C}\right)$

melt rate $(\mathrm{kg} / \mathrm{h})=$ weight of water collected divided by test time

latent heat $=335 \mathrm{~kJ} / \mathrm{kg}$ 
The system R-value includes the size and shape of the container, the wall material and thickness and to some extent, the effect of the product. As such it is the property of the whole package, not just the insulating material.

\subsection{Melting point and latent heat for gel packs and PCMs}

In this study, 12 different types of commercially available gel packs and PCMs were evaluated for their thermal properties, namely melting point and latent heat. The term gel pack is used for materials composed primarily of water. The term PCM is used for materials other than water. Gel packs have properties similar to water. PCMs can be formulated to have properties very different from water.

\subsubsection{Melting point determination.}

For determining the melting points, two of each type of gel packs were frozen. A thermocouple was then placed between them and the entire setup was wrapped in aluminum foil to limit heat loss. The setup was then placed in an insulating container and temperature versus time data was monitored. Melting was observed on the time versus temperature plot as the flat part of the curve (Figure 15). To validate this procedure, plastic bags filled with tap water were used as gel packs. The measured melting point was $0.06^{\circ} \mathrm{C}$, which is very close to the known melting point of $0^{\circ} \mathrm{C}$.

\subsubsection{Latent heat and heat absorption determination.}

The latent heat of the gel pack materials was also determined. A bucket big enough to hold the gel packs was obtained, as was a good insulating package big enough to hold the bucket. The buckets were filled with enough water to submerge the gel pack. The buckets, water and gel packs were weighed separately. The water was conditioned in a test room for $24 \mathrm{~h}$, and the gel pack was frozen for the same duration. After $24 \mathrm{~h}$, the frozen gel packs were quickly submerged in the equilibrated water. A thermocouple was then placed in the water and the bucket was placed in the insulating package, which 


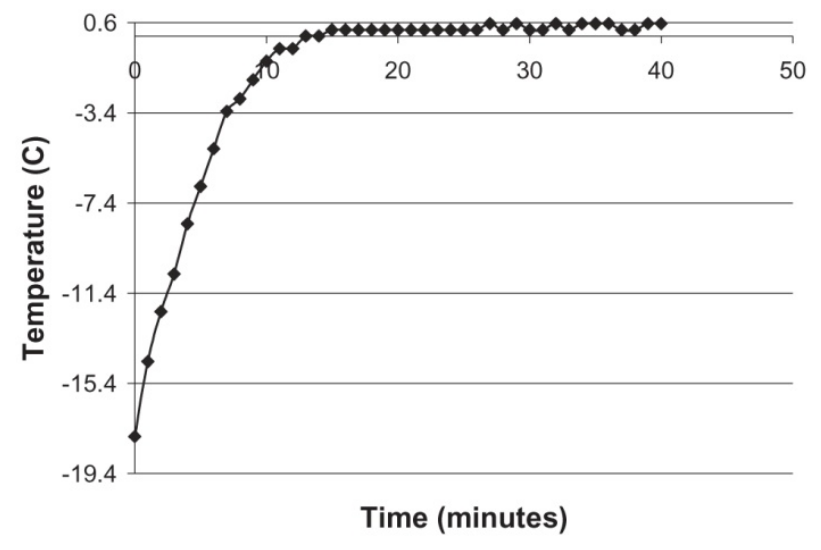

Figure 15. Melting point plot for water bags.

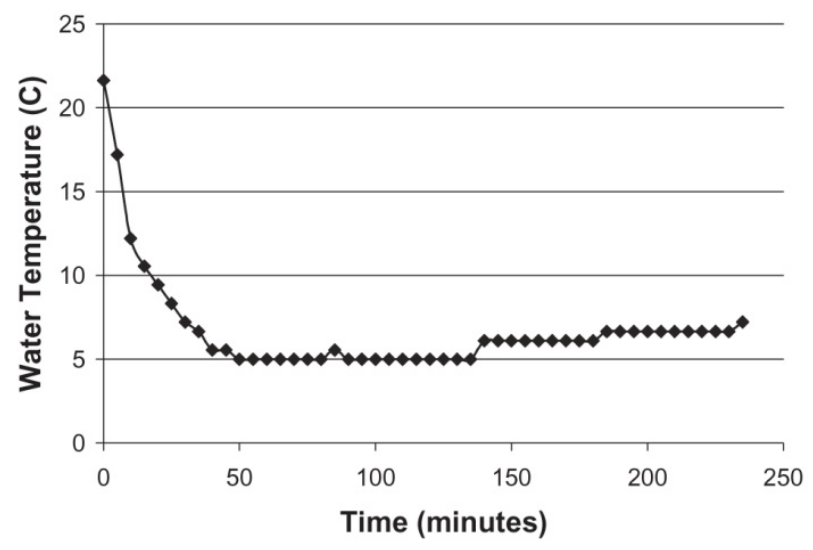

Figure 16. Latent heat experiment results.

was then sealed. The lowest temperature reached by water was recorded. The latent heat was calculated from the heat balance:

\section{Heat lost by water $=$ Heat gained by gel pack}

To validate this procedure, frozen water bags were used as gel packs and the procedure mentioned above was used to determine the latent heat of water as follows:

- water + bucket weight $=5.5 \mathrm{~kg}$

- gel pack (water bag) weight $=0.9 \mathrm{~kg}$ 
- freezer temperature $=-18^{\circ} \mathrm{C}\left( \pm 2^{\circ} \mathrm{C}\right)$

- starting water temperature $=20.94^{\circ} \mathrm{C}$ (Figure 16)

- lowest water temperature $=4.89^{\circ} \mathrm{C}$ (Figure 16)

- calculated latent heat for water $=345 \mathrm{~kJ} / \mathrm{kg}$

- known value for pure water $=335 \mathrm{~kJ} / \mathrm{kg}$

\section{RESULTS}

\subsection{System R-value results}

System R-values of 12 different insulated container systems were measured using three replicates each for $24 \mathrm{~h}$. Containers 2 and 3 were tested for $12 \mathrm{~h}$ because of high melt rates of ice. Two different insulated bags were also tested. The bag tests were only conducted for $2 \mathrm{~h}$ since the ice melted much faster. The weight of water collected at the end of tests was converted into melt rates, which in turn gave system R-values using the equation in section 3.2. The results are summarized in Tables 4 and 5.

\subsection{Melting point and latent heat results}

Melting points and latent heats were measured using three replicates with the method specified in 3.3. The results are summarized in Table 3 below.

\section{USE OF RESULTS}

The system R-value and the thermal properties of gel packs can be used to estimate the amount of gel packs needed to keep a product cool during distribution. The following example illustrates the calculations. 
Suppose that the package in Figure 1 (corrugated box lined with 19-mm-thick EPS panels) is used to keep a temperature-sensitive product cool for $48 \mathrm{~h}$ in a $27^{\circ} \mathrm{C}$ environment. How many kilograms of 'Polar Pack' gel packs are required to keep the product near $0^{\circ} \mathrm{C}$ for the $48 \mathrm{~h}$ trip?

The calculations are as follows:

- system R-value (Table 4) $=1.66 \mathrm{~m}^{2} \mathrm{C} / \mathrm{W}$

- gel pack latent heat $=314 \mathrm{~kJ} / \mathrm{kg}$ (Table 3)

- inside surface area $=[2(28 \times 28)+2(28 \times 30)+2(28 \cdot 30)] / 10000=0.4928 m^{2}$

\begin{tabular}{|c|c|c|}
\hline \multicolumn{3}{|c|}{ Table 4. System R-values for containers } \\
\hline Package & Insulated container systems & $\begin{array}{c}\text { Average R-values }\left(\mathrm{m}^{20} \mathrm{C} / \mathrm{W}\right) \\
24 \mathrm{~h}\end{array}$ \\
\hline Ia & C-Flute corrugated fibreboard box with $19 \mathrm{~mm}$ EPS foam panels & 1.66 \\
\hline $\mathrm{Ib}$ & C-Flute corrugated fibreboard box with $13 \mathrm{~mm}$ EPS foam panels & 1.63 \\
\hline 2 & C-Flute corrugated fibreboard box & $1.05 *$ \\
\hline 3 & Oyster ThermalCor® box & $1.25^{*}$ \\
\hline 4 & ThermalCor $₫$ box with ThermalCor $\AA$ tube & 1.41 \\
\hline 5 & Foil ThermalCor $₫$ box & 1.69 \\
\hline 6 & Foil ThermalCor ${ }^{\circledR}$ box with $4.8 \mathrm{~mm}$ inch foil bag insert & 1.91 \\
\hline 7 & EPS container with lid & 2.00 \\
\hline 8 & Polyurethane foam moulded container & 2.56 \\
\hline 9 & ThermalCor $₫$ box in a ThermalCor $\AA$ box & 1.29 \\
\hline 10 & Foil-laminated ThermalCor ${ }^{\circledR}$ box in a ThermalCor ${ }^{\circledR}$ box & 1.73 \\
\hline II & ThermalCor® box in a foil-laminated ThermalCor ${ }^{\circledR}$ box & 1.48 \\
\hline 12 & Foil-laminated ThermalCor ${ }^{\circledR}$ box in a foil-laminated ThermalCor ${ }^{\circledR}$ box & 1.73 \\
\hline *Tested & & \\
\hline
\end{tabular}

\begin{tabular}{|lcc|}
\hline \multicolumn{3}{|c|}{ Table 5. System R-values for bags } \\
Package & Insulated bag systems & Average R-values $\left(\mathrm{m}^{2 \circ} \mathrm{C} / \mathrm{W}\right) 2 \mathrm{~h}$ \\
\hline 13 & Keep Cool $\AA$ insulating bag & 0.58 \\
14 & Therm-A-Snap $\AA$ insulating bag & 0.46 \\
\hline
\end{tabular}

Using the system R-value equation in 3.2,

$1.66=\frac{(0.49)(27+1.1)}{(\text { Melt rate })(314)}$ 
where the melt rate is $95 \mathrm{~g} / \mathrm{h}$. If the product is to stay cool for $48 \mathrm{~h}$, then the gel packs will have to stay frozen this long. At a melt rate of $95 \mathrm{~g} / \mathrm{h}$, there would need to be $48 \mathrm{X} \cdot 95=4560 \mathrm{~g}$ or $4.6 \mathrm{~kg}$ of Polar Pack.

\section{CONCLUSIONS}

The following conclusions were drawn based on the R-value results in Table 4:

- Foil ThermalCor ${ }^{\circledR}$ boxes with bag were not significantly different than foil ThermalCor ${ }^{\circledR}$ boxes without bag (package 5 versus 6). Over-wrap of foil bubble wrap was not effective.

- Lamination of foil on ThermalCor ${ }^{\circledast}$ (package 5) improved the R-value compared with no foil (package 3).

- $19 \mathrm{~mm}$ EPS foam panels (package 1a) improved the R-value of plain corrugated (package 2) by 3.5 units and $13 \mathrm{~mm}$ EPS foam panels (package $1 \mathrm{~b}$ ) by 3.3 units.

- The polyurethane foam moulded container (package 8) yielded the highest R-value followed by the EPS container with lid (package 7).

- ThermalCor ${ }^{\circledR}$ containers with various alternative configurations (packages 3, 4, 5, 6, 9, 10, 11 and 12) did not show a significant difference in the R-values.

- The Keep Cool ${ }^{\circledR}$ (Keep Cool USA LLC, Mount Pleasant, SC, USA) bag has greater thermal resistance than the Therm-A-Snap ${ }^{\circledR}$ (The Carry Cool Company, Fort Lauderdale, FL, USA) bag.

Additional conclusions based on the thermal data for gel packs in Table 3 are:

- The melting points and latent heats of most of the gel packs tested were very similar to water.

- Phase change latent heats are similar to that for water. 
- The shape of the gel packs plays a significant role. With large surface and small volume, gel packs melt faster but keep the product cooler and with small surface and large volume, the gel packs last longer but the product is not as cold.

\section{REFERENCES}

1. Brown Al, Marco SM. Introduction to Heat Transfer, 3rd ed. McGraw-Hill Book Company Inc.: New York, 1958.

2. Burgess G. Practical thermal resistance and ice requirement calculations for insulating packages. Packag. Technol. Sci. 1999; 12(2): 75-80.

3. Desjarlais AO, Zarr RR. Insulation Materials: Testing and Applications, Vol. 4. ASTM International: West Conshohocken, PA, USA. 2002, ISBN: 0-8031- 2898-3.

4. Anderson N. Technology Assessment: Technology Viable to Keep 'Take-Home' Food Warm for 30 Minutes. MS Research Paper, Management Technology, University of Wisconsin-Stout, 2003.

5. Cabeza LF, Marin JM, Mehling H, Zalba B. Review on thermal energy storage with phase change: materials, heat transfer analysis and applications. Appl. Therm. Eng. 2003. 23(3): 251-283.

6. Hy-Tech Thermal Solutions. http://ceramicadditive.com/conduction_heat.html [accessed 10 October 2006].

7. Polin JB. Shipping temperature-sensitive products. Pharmaceutical \& Medical Packaging News. 2002; http://www.devicelink.com/pmpn/archive/02/02/005.html [accessed 10 October 2006]. 
8. Johnson T. (ed.). Alaska Fisherman's Direct Marketing Manual, Publication No. MAB-53. Alaska Department of Commerce and Economic Development and Alaska Seafood Marketing Institute: University of Alaska, Fairbanks, USA, 2005.

9. Report. Mekong Freight Logistics Study. The Cool- Chain. Australian Government, Department of Transport and Regional Services. 2002; http://www.dotars.gov.au/index.aspx [accessed: 10 October 2006]. 